\title{
A Reflection of Ian McEwan's Life in His Fiction
}

\author{
Mina Abbasiyannejad (Corresponding author) \\ English Department, Faculty of Modern Languages and Communication \\ University Putra Malaysia, Serdang, Selangor, Malaysia \\ Tel: 60-17-638-2190 E-mail: minaabbasiyannejad@gmail.com
}

Rosli Talif

English Department, Faculty of Modern Languages and Communication

University Putra Malaysia, Serdang, Selangor, Malaysia

Tel: 60-19-281-5654Ｅ-mail: rosli@fbmk.upm.edu.my

Marjan Heidari

English Department, Faculty of Modern Languages and Communication

University Putra Malaysia, Serdang, Selangor, Malaysia

Tel: 60-17-682-0264 E-mail: marjanheidari2012@gmail.com

Received: December 18, 2011

Accepted: April 27, 2012

Published: June 1, 2012

doi:10.5539/ells.v2n2p56

URL: http://dx.doi.org/10.5539/ells.v2n2p56

\begin{abstract}
This article aims to show why Ian McEwan is so obsessed with relationships, as well as with other socio-cultural issues such as class difference, sense of loss, music, role of parents, and with certain mental illnesses, in his fiction. McEwan also makes very pronounced use of the aforementioned issues in different ways and colours his fiction with them, one way or another. Examining McEwan's life reveals that he experienced quite troubled circumstances and, as he himself admits, his writing can never escape from his background, so this is mirrored in his work. His obsession with language is also clear in much of his work. This article investigates McEwan's life with the help of several interviews and articles written by him about his life, particularly relating to his childhood and family background. This article examines various aspects of his life, from childhood to maturity, and shows the reflection of Ian McEwan's life in his work.
\end{abstract}

Keywords: Ian McEwan, Childhood, Reflection, Fiction, Class, Conflict

\section{Introduction}

The macabre themes of violence, incest and isolation in McEwan's earlier works became the focus of attention for critics and reviewers. He began his work with two collections of short stories, First Love, Last Rites and In Between the Sheets, which highlight the darker side of humanity. Ryan Roberts (2010) explains that McEwan " has dealt with a wide range of human experiences, including the effects of losing a child, religious fervour, psychological obsession, the intricacies of relationships, euthanasia, and happiness in a modern word bent on conflict and destruction" (p. x).

The end of Britain's imperial power is reflected in economic, political and cultural crises in the 1970s, and as a clear social, cultural and moral decline. The onset of recession led to further decline: "growing conflict and terrorism in Northern Ireland, a miners' strike, and then a serious balance of payments deficit, weakened successive governments, and all culminated in the Winter of Discontent of 1978, which opened the way for Mrs Thatcher and Thatcherism" (Groes, p. 6). McEwan channelled these events into a dark gothic world, and his writing basically deals with murder, incest and paedophilia, generally dark and disturbing issues, which led to him being labeled "Ian Macabre" or a "literary psychopath". Although there is a shift away from the early dark issues to more social and cultural issues in his later works, they still "contain many of the themes and obsessions that he continues to explore, in a more subtle and refined way" (Groes, p. 7). 
Head concluded that there was: "a reflection of a complex, paradoxical world whose multiplicity constantly perplexes and confounds us, McEwan's fiction is often confusing and ambiguous. The uncertainty reflects the troubled state of the world at the beginning of the 21st century [but] McEwan's work will continue to explore ... what days are these"(Groes, p. 12). As Jago Morrison (2001) in the article "Narration and Unease in Ian McEwan's Later Fiction" asserts, what makes Ian McEwan's writing especially worthy of attention is the way in which his experimentation with time and narrative is interlinked with a rethinking of gender identity. McEwan tells Begley that writing is "a process you can't have, and don't want, under your full conscious control".

McEwan, as a well-known contemporary writer, has great interest in relationships, particularly incompatible relationships. Zadie Smith (2005) says that McEwan's prose is "controlled, careful, and powerfully concise; he is eloquent on the subjects of sex and sexuality" (p. 108). She also admires McEwan's brilliant employment of metaphors in this way, "when I read him, I am struck by metaphors I would never think to use" (p. 108), and also asserts that "picking up a book by McEwan is to know, at the very least, that what you read therein will be beautifully written, well-crafted, and not an embarrassment, either for you or for him" (p. 108).

His characters deal with conflicts in their lives in a way that makes it clear they feel helpless and unable to solve their problems. McEwan is also remarkably obsessed with class difference in most of his works. He creates people from different classes, and normally the lower class is abused and made to suffer by the upper class. He also reconsiders the sexual boundaries of the past and how they influence people's lives, e.g. separate schools for boys. His tendency toward feminism and women issues is shown in his works. He also has an ability to visualize the atrocities and brutalities of war which basically comes from his father's descriptions of his experiences. He believes that, when a writer writes, he is under the influence of his unconscious. This paper will present some important events of McEwan's life that had an indelible effect on him, and how, inevitably, he writes about or reflects them in his work. This paper examines most of his prominent work.

\section{Discussion}

In an interview with John Haffenden (1983), McEwan maintains that his first collection of short stories, First Love, Last Rites, was reminiscent of changing events in his own life (p. 30). He reveals that, in the writing of The Imitation Game, he stepped out into the world consciously to find out about a certain time in the past and to recreate it - create it - and at that point he felt he had made a very distinct change. But when he came back to The Comfort of Strangers he found himself immediately being drawn again into a very private world, without quite intending it, where psychological states once more become more important than relationships between, for example, individuals and their societies. These things are not entirely within one's control, and he does not think they should be (p. 31).

McEwan and Allen, his wife, separated, and in 1999 they argued over the custody of their son, Greg. Allen ran off with their son to France, consequently McEwan and his friend, Timothy Garton Ash, followed them to France. At that time McEwan was living through the nightmare of "The Child in time" (Zalewski, 2009, p. 8). This shows that the nightmarish and torturous time that he had gone through after his son was kidnapped inspired him to write the story of a little girl who was kidnapped in a supermarket.

McEwan's story, The Comfort of Strangers was inspired by his trip with his wife to Venice in 1978. He asserts that, "something of our visit found its way into the book." After having been to Venice, they returned and McEwan made some notes about it, which were lost and then found one and half years later. "It seemed to me that I had already been describing two characters who were not quite like either myself or Penny, and already it seemed to be describing the city in terms of state of mind, and vice versa. So the novel took off from the notes. Those notes contain the phrase "self-fulfilling accusation", as well as the first sentence, so I must have been thinking about a novel even then" (p. 35). McEwan is a unilateralist and says that his anxiety over nuclear weapons will be reflected in his art. He says that "it's impossible to keep this preoccupation out, because it is so personal".

\subsection{Primary Wars in the Twentieth Century}

Kate Kellaway (2005) explains that how McEwan's life was affected by the twists and turns of war. She refers to McEwan's childhood when the "detritus of war was always around him". He explains that even "his baby sitters were corporals" (Para 24). In an interview with Jonathon Noakes, in the book named Ian McEwan (2002), McEwan explains his representation of violence and war in his work. He says that war had a great influence on his family; although he was born in 1948, he did not get away from the consequences of the Second World War. He emphasizes the shadow of war on his life in this way:

The war shaped our family life... It was the war that killed my mother's first husband. I grew up in army camps in places in the world in which, again, our presence was to some extent determined by the recent war. And then, more importantly, I suppose, it was the war that set in place the alignments of countries that brought us into the Cold War. 
It was such a constant presence in my childhood (p. 20,21).

McEwan not only has the power to write about war and its consequences, but he can also visualize conflict brilliantly and make the reader see events clearly. He employs different signs and tries to visualize events. McEwan says, "you have got to make your reader see and when people accuse me of being too graphic in my depiction of violence, my response is, 'well... you've got to show it in all its horror"' (Reynolds \& Noakes, 2002 p.22, 23). McEwan states that many of the images he used for Dunkirk were taken from the Bosnian conflict; he used photographs to remind himself how soldiers and civilians suffered the consequences of war (Reynolds et al., 22). And he also recalls that his father revealed vivid memories of Dunkirk in an interview in 1989 (Zalewski, 2009, p. 6). In another interview he admits as well that the section devoted to Dunkirk in Atonement is a tribute to his father (Lynn, 2006).

McEwan says that his father's death "was unconsciously reflected in the number of absent fathers in his novels. The men who straggled towards Dunkirk would have been aware that their fathers had died or fought in this same stretch of northern France" Lynn, p. 105). He also states that his father "makes an appearance in Atonement. In 1940 he was a motorbike dispatch rider and he was wounded in the legs. He teamed up with another soldier who'd been shot in the arms, and between them they worked the controls of a motorbike. They passed Robbie on the road into Dunkirk" (p. 89).

He also admits that "there is something of myself in Peter of the Daydreamer. I was an intimate sort of child who never spoke up in groups. I preferred close friends" (p. 90). In his interview with David Lynn (2006), McEwan insists that Henry Perowne in the novel Saturday "is not me, although I gave him one or two elements of my own life". He continued and said, "I gave him my house; I gave him little bits of my children, of my wife. I gave him in its entirety, a relationship with my mother, who also suffered from a neurodegenerative disease" (p. 144). In the same vein, McEwan, in an interview with David Remnick (2007), explains how his life around him creeps into his work, Saturday. He said that, "I gave my hero my new house. I gave him one of my children. I explored my new neighbourhood with him; the hospital where he worked was where I did all my research. As for my mother, I hoped the novel would be a memoir, a testimony to this process of slow disintegration. Everything, even the squash games, everything, I just let it all pour in" (p. 169)

\subsection{Class Conflict}

The Encyclopaedia of Contemporary British Culture (1999) defines Social class system as the main division in British politics. Different features represent class distinctions. This "includes occupation, income, material possessions, family position, breeding, accent, education, appearance, lifestyle, and power. Traditionally, the British population has been separated into social classes which were assumed to have a common identity, and class consciousness and solidarity" (p. 107). The idea of social class and its role in everyday life is repeatedly discussed in McEwan's works.

Gerhard Emmanuel Lensk, in his book Power and Privilege: A Theory of Social Stratification (1966) indicates that man as a social being has no control on the society in which he was born, and "he is often unaware" (p. 26). Peter Berger expresses this well he wrote: "society not only controls our movements, but shapes our identity, our thought and our emotions. The structures of society become the structures of our own consciousness. Society does not stop at the surface of our skins. Society penetrate us as much as it envelopes us. (Peter Berger, 1963, as cited in Gerhard Lensk, 1966).

McEwan's obsession with class conflict is rooted in his family background, and his mother was especially conscious of this class discrimination. In his article "Mother Tongue" (2001), he indicates that his mother was always uneasy and aware of her accent, particularly when she encountered people of higher social rank. Similarly, in an interview with Zadie Smith (2005), McEwan comments on his mother's awareness of her accent and language, of belonging to a working class family, and how his mother's "hesitancy in language was a crucial element of [his] English class position". He also states that his father was commissioned from the ranks, though he did not have a university degree; he was not "posh" so the other officers in the group that came from Sandhurst would "look down" on him (p. 117). McEwan writes about his extreme care with language in the "mother tongue" (2001) how he spends long hours framing a sentence in his mind, and only when he is totally sure that everything is "secure and complete" does he write it down. After that he asks himself, "Did it really say what I mean? Did it contain an error or an ambiguity that I could not see?" (Para 12).

In On Chesil Beach, (2007) Edward comes from a lower middle class family, while his wife to be belongs to the upper class. The social gap between them is basically shown by representing occupation and lifestyle. Florence lives in a big Victorian villa while Edward lives in a rather humble small house. In another place it is mentioned that Edward has never experienced staying at a hotel, while for Florence it is something usual (p. 3). In the same way in 
Atonement, Cecilia and Robbie, the protagonists of the story are from two different social backgrounds. Cecilia comes from upper class society whereas Robbie is their cleaning lady's son. "She always seemed to find it awkward - 'that's our cleaning lady's son' " (p. 74). In Black Dogs there are some signs that reveal a character's irritation by the character's attitude toward lower class people, e.g., when June accused Bernard of never caring about working class people and even loathing them (p. 55).

\subsection{Role of Parents}

Something that is significant in McEwan's work is his presentation of the role of parents. McEwan's father's role, as previously mentioned, is almost absent; it is faint and trivial in his life. In a conversation with Ian Hamilton (1978), McEwan talks about his army background, with parents of totally different personalities. He explains the conflict between his parents in this way: His father, David, was an officer with a very domineering personality, but his mother was very gentle (p. 3). Perhaps what makes McEwan concerned about the relationship between dominator and subordinator like the way he presents male and female characters is rooted in what he observed from his relationship with his parents. He considers his father was "as an intruder into my rather intense, pleasant relationship with my mother" (p. 4) and this is expressed in his work in different ways. In a conversation with Adam Begely (2002), McEwan asserts that the narrator's parents in the book, The Child in Time are "fairly close" to his parents, "though somewhat idealized" (p. 89). He talks about his parent's difficult relationship and his unwillingness to write about them while they were alive (p. 89). McEwan also indicates that the scene in which the mother is weeping in The Child in Time is expressing his mother's life, because, "My father's drinking was sometimes a problem. And a great deal went unspoken" (p. 90).

As for his father's role, McEwan said about him, in a conversation with Adam Begley (2002), "He didn't have much talent for communicating with small children. Both my mother and I were rather frightened of him" (p. 89). The role of fathers in Atonement almost disappears in the story, almost the same as McEwan's father's role in his own life. There is almost no sign of either Jack Tallis, Cecilia's father, or Robbie's father in Atonement. He explains Jack's absence with various excuses, such as "Jack was working far too hard" (p. 412). Or they call him the Old Man when they say, “And the Old Man's staying in town?" (p. 70). Along the same lines, Robbie's father left his family when Robbie was only six years old, without any warning, not even taking any luggage with him, (p. 122). In an interview with Begley, McEwan explains that his "mother worked into service as a chambermaid" (p. 89). In the same vein, in Atonement, Robbie's mother, Grace Turner, works as a chambermaid for the Tallis family.

In Black Dogs, the narrator lost both parents when he was only eight years old and all through his life tries to find his parents' surrogates. It could be McEwan's own desire to pursue the ideal parents, intellectual, wealthy and, at the same time, friendly. In Black Dogs (1992), the narrator said, "Ever since I lost mine in a road accident when I was eight, I have had my eye on other people's parents" (p. xiii). In his interview with John Haffenden (1983), he said he had the same experience when he was twenty-one years old; he began to meet people who had intellectual parents. He would visit their houses in the role of the boyfriend who had to be tested for his opinions (p. 46). In On Chesil Beach, parental loss is shown in another way. Edward's mother suffers a mental illness that practically erases her role as a mother in Edward's life, and puts all the burdens of life on Edward's father's shoulders. In McEwan's own life, his father was almost absent but his mother was close to him.

His feeling of rootlessness in terms of location can be seen in Leonard Marnhem, his protagonist in his book The Innocent. McEwan, in an interview with Zadie Smith, (2005) explains that, because of his father's job, they could not stay in one place for very long, so "I'm not rooted in any particular place" (p. 117).

In an interview with Liliane Louvel, in the case of his mother, he revealed that he had inherited the shy nature of his mother (p. 74). In an interview with Charlie Rose, McEwan (2007) admits that, in the matter of sex, he was a late starter. His being shy and reserved can be seen in some of his work, such as The Innocent, Atonement and On Chesil Beach, at different levels. Edward, the protagonist of On Chesil Beach, is still a virgin at the age of twenty-two. His shyness makes him unable to reveal his true desires for his lover. And Leonard, the protagonist in The Innocent, establishes his first loving relationship at the age of twenty-five while still a virgin at this age. Comparing Leonard to other fellows, he is shy, reserved and even naive. Robbie, in Atonement, is shy in another way, and unable to reveal his true feelings to his lover. His behaviour expresses his bashful attitude toward encountering the opposite sex.

In an interview with Liliane Louvel, et al. (1995) he admits that the narrators of the short stories, such as Butterflies, and conversations with the cupboard man, are "alienated figures" and "excluded from society". He also asserts that the characters "bear some relationship to him". He explains that he was confused about his real place in British society. Both his parents were from the working class. His father became an officer based on his experience rather than on his level of education and that made the family feel a "kind of dislocated existence" (p. 69). 
In the same interview, McEwan explains why his themes are always interwoven with "loss, deprivation and absence". He believed that under the influence of his unconscious he wrote the story of The Last Day of Summer, which is about a boy who is involved in a rowing accident, causes the death of a mother figure and a small baby. He later on explains that when he was in his thirties he came to the realization that the story was the reflection of his own thoughts or feelings. "The woman in the boat is clearly my mother, the baby in the boat clearly myself, as is the boy." The drowning scene shows both the death of his mother and his childhood (p. 73). He had experienced these feelings when he was sent to boarding school at the age of eleven.

Regarding family connections, there is always a complex and ambivalent relationship with a father figure or a father substitute in his work. McEwan said that, "he was precisely one of those figures from my fiction who seemed to want to make me over" (p. 74). He employs an ironic father figure in Solid Geometry, a sadistic father in the Comfort of Strangers, or a positive father-son relationship, as in the Child in Time, and the substitute relationships between the narrators in Black Dogs. McEwan says that the father figures in his work are a reflection of his own father.

He was a "powerful, domineering, slightly bullying man"; he really loved him but both in a "supportive" and "oppressive" way. He admits that his father was exactly the figure portrayed in his fiction, that he never had an intimate and loving relationship with his father, because he actually feared him (p. 74). He continues to talk of his father and says that one of the reasons why he was interested in Kafka was that, "He addressed his father in a long letter. I ended up addressing mine with stories and novels. In The Cement Garden, I killed him off early on. He's there in The Comfort of Strangers, and he pops up in other places, In the later fiction, I've tried to redeem him by becoming the father, by trying to take his strengths, his huge capacity for love and giving it expression"(p. 75). The absence of the father can be seen in more of McEwan's work, such as Atonement. The faint presence of Jack Tallis, the father of the family, is quite tangible in the story.

\subsection{Neurological Disease}

McEwan's mother suffered from a neurological disease, vascular dementia, which gradually erased her memory. In the article "Mother Tongue", he describes his own mother's progressive disease in this way: "It is 1994, still many years to go before the first signs of the vascular dementia that is currently emptying her mind" (Para. 2). This has resonated in Ian McEwan's main characters, such as Briony Tallis in Atonement (2001) Briony explains her sickness. "I have vascular dementia, the doctor told me, and there was some comfort to be had...loss of memory, short- and long-term, the disappearance of single words - simple nouns might be the first to go - then language itself, along with balance, and soon after, all motor control, and finally the autonomous nervous system" (p. 334, 335).

In Saturday, another novel by Ian McEwan, Henry Perowne, the protagonist of the story, has a mother who suffers from vascular dementia. This does not end with these two novels; there is also neurological disorder in other novels. In Amsterdam, McEwan describes characters, 46-year-old Molly, as someone suffering from rapidly progressing dementia:

It began with a tingling in her arm as she raised it outside the Dorchester Grill to stop a cab - a sensation that never went away. Within weeks she was fumbling for the names of things. Parliament, chemistry, propeller she could forgive herself, but less so bed, cream, mirror. It was after the temporary disappearance of acanthus and bresaiola that she sought medical advice, expecting reassurance. Instead, she was sent for tests and, in a sense, never returned. How quickly feisty Molly became the sickroom prisoner of her morose, possessive husband, George (p. 3, 4).

\subsection{Role of Music}

Eric Friesen (2009), in his interview with Ian McEwan, reveals that McEwan's interest in music is reflected in his characters in different ways. They are connected to music, as listeners, players or composers. Despite the fact that his parents were not musically inclined, receiving a "huge reel-to-reel recorder" from them as a birthday present provoked his interest in classical music. McEwan points out that two of his central female characters, Julie in the novel The Child in Time and Florence in On Chesil Beach, are violinists in string quartets (p. 417). In Saturday, the male character, Henry Perowne, is also connected to music by playing it in the operating theatre (p. 418). In Amsterdam, (1998) one of the male characters is a famous English composer. He also asserts that in the word Tallis in Atonement, there could be a throwback to Thomas Tallis, the great English renaissance composer. McEwan also drew on his love of classical opera, particularly Mozart, for the shape of this work (p. 422).

\section{Conclusion}

McEwan's themes vary from his early work to his later material, but one thing that remains the same is his eloquent style of writing. His meticulous and expressive language has roots in his background, particularly the effect of his mother's language. Belonging to a lower social class made her quite conscious of the way people viewed her, 
therefore she was always class-conscious. McEwan as a child almost always accompanied his mother and was affected by her attitude toward 'posh' people. He presents people from the lower and upper classes in many of his works and shows how people with upper-social-class status can manipulate the lower class's life. This paper has explored McEwan's life through his many interviews with various parties, his articles and anything that might shed light on different aspects of his life in order to identify how much of his work was influenced by his own personal life. By examining several informative sources, this work demonstrates that his work is influenced in different dimensions, by a number of events and circumstances that took place in his own life, personally and in the lives of others he grew up with - his father and mother - and his peers within his social-economic class. Relationships are definitely one of the most important issues in McEwan's work, although history and culture play a significant role in his work in which he constantly embodies different aspects of relationships, such as between couples, parents and children, colleagues, and generally any kind of connection. The portrayal of conflict in relationships, the class war, sense of loss, most frequently parental loss, or particularly a father's absence in children's lives, the role of music and the constant presence of the Second World War are among the most important issues that permeate the works of Ian McEwan.

\section{References}

Begley, A. (1993). The Art of Fiction Cxxxv: Don Delillo. Conversation with Ian McEwan. In R. Roberts (Ed.), Paris Review, 35, 274-306.

Childs, P., \& Storry, M. (1999). Encyclopedia of Contemporary British Culture. London \& New York. Routledge. Friesen E. (2009). The Writer Who Listens ...Ian McEwan interviewed. Queen's Quarterly, 116(3), 415-424.

Groes, S. (2009). Ian McEwan: Contemporary Critical Perspectives. London: Continuum Intl Pub Group.

Haffenden, J. (1983). Ian McEwan. In R, Roberts (Ed.), Conversations with Ian McEwan. pp. 26-46.

Hamilton, I. (1978). Points of Departure. In R. Roberts (Ed.), Conversation with Ian McEwan. The New Review, 5 , 9-21.

Kellaway, K. (2001). At Home with His Worries. The Observer. [Online] Available: http://www.guardian.co.uk/books/2001/sep/16/fiction.ianmcewan

Lenski, G. E. (1966). Power and Privilege: A Theory of Social Stratification. New York. Univ of North Carolina Pr.

Liliane. L. Gilles, \& Fortin, A. L. (1995). An Interview with Ian McEwan. In R. Roberts (Ed), Conversations with Ian McEwan. pp. 67-78.

Lynn, D. (2006). A Conversation with Ian Mcewan. In R. Roberts (Ed.), Conversations with Ian McEwan. pp. 143-155.

McEwan, I. (1998). Amsterdam. New York: Anchor.

McEwan, I. (1993). Black Dogs. Canada: Vintage.

McEwan, I. (2001). Mother Tongue. [Online] Available: http://www.ianmcewancom/bib/articles/mother-tongue. $\mathrm{Html}$

McEwan, I. (2007). On Chesil Beach. London: Anchor.

McEwan, I. (1998). The Innocent. London: Anchor.

Morrison, J. (2001). Narration and Unease in Ian McEwan's Later Fiction. Critique: Studies in Contemporary Fiction, 42(3), 253-68. http://dx.doi.org/10.1080/00111610109601143

Remnick, D. (2007). Naming What Is There: Ian McEwan in Conversation with David Remnick. In R. Roberts (Ed.), Conversations with Ian McEwan. pp. 156-175.

Reynolds, M., \& Noakes, J. (2002). Ian McEwan: The Essential Guide. Great Britain: Vintage Books.

Roberts, R. (2010). Introduction. Conversations with Ian McEwan. United States of America. Jackson MS: University Press of Mississippi.

Smith, Z. (2005). Zadie Smith Talks with Ian McEwan. In R, Roberts (Ed.), The Believer Book of Writers Talking to Writers. pp. 207-39.

Zalewski, D. (2009). The Background Hum. The New Yorker, 23, 46-61. 